\title{
"A woman should not be so cheap" The Prostitute as a Constructed Other in Estonian Post-Soviet Life Stories ${ }^{1}$
}

\author{
Riikka Taavetti
}

University of Helsinki

\section{ABSTRACT IN ENGLISH}

This article discusses the construction of the female prostitute figure in Estonian life stories on love and sexuality that were collected in 1996. As prostitution was mentioned in the questions posed in the call for writings, more than half of the 61 respondents discussed their attitudes as well as experiences concerning prostitution. The writers portray prostitution as a stable phenomenon that is needed in society; one that cannot be eradicated but should be controlled. Additionally, prostitution is connected to the spread of sexually transmitted diseases and particularly to AIDS. The image of prostitution constructed in the writings carries ethicised meanings as it is exoticised as well as portrayed as something inherently Estonian. The main point in this article is that the figure of the female prostitute was constructed as an 'other' in the life stories, a sexual outsider who is needed in the society but who is nonetheless perceived as essentially different from the writers themselves. The contributors used this othering in their writing to construct their selves as well as the concept of acceptable heterosexuality.

Keywords: post-socialism, sexuality, prostitution, Estonia

\section{ABSTRACT IN FINNISH}

"Niin halpa naisen ei pidä olla" Prostituoitu konstruoituna toisena virolaisissa Neuvostoliiton hajoamisen jälkeisissä elämäkerroissa. 
Artikkeli käsittelee naisprostituoidun hahmon rakentumista virolaisissa rakkaus- ja seksuaalielämäkerroissa, jotka kerättiin vuonna 1996. Prostituutio mainittiin kirjoituskutsun kysymyksissä ja yli puolet keruun 61 kirjoittajasta kertoi omista asenteistaan seksin myymiseen ja ostamiseen sekä lisäksi prostituutioon liittyvistä kokemuksistaan. Kirjoituksissa prostituutio kuvataan pysyvänä ilmiönä, jota ei voida poistaa, mutta jota pitää kontrolloida. Kirjoittajat liittävät prostituution sukupuolitautien ja erityisesti aidsin leviämiseen. Prostituutioon liitetään myös etnistyneitä käsityksiä, joissa prostituutio yhtäältä eksotisoidaan, mutta toisaalta sitä kuvataan erityisen tyypillisenä virolaiselle yhteiskunnalle. Artikkelissa esitetään, että kirjoittajat rakentavat naisprostituoidun hahmon seksuaaliseksi "toiseksi", ulkopuoliseksi, jota yhteiskunta tarvitsee, mutta joka on olemuksellisesti erilainen kuin millaisena kirjoittajat näkevät itsensä. Kirjoittajat käyttävät toiseuttamista ja toiseutetun prostituoidun hahmoa konstruoidessaan kirjoituksissaan omaa itseään sekä hyväksyttävää heteroseksuaalisuutta.

Prostitution is sex for money. It is the world's oldest profession, and is it not everyone's own business how they earn money. Why blame prostitutes when flocks of 'loyal' married men use their services. ${ }^{2}$

The above quotation was written by an Estonian man, born in 1951, and submitted to a life story collection in 1996. He and sixty fellow Estonians shared their memories of love, sexual experiences, dreams and disappointments, and described their various positions on topics concerning sexuality. By composing his life story, this writer not only participated in the comparative study of Finnish researchers but also contributed to the public construction of Estonian post-Soviet sexuality, as these life stories were utilised in research and a selection of them formed the basis for an anthology and a theatre play.

As prostitution was mentioned in the questions posed in the call for writings, over half of the respondents at least briefly stated their opinions, and a few wrote of personal experiences involving prostitution. I suggest that these representations of prostitution in the life stories are mentioned not only to describe what prostitution was, but were also used to construct the female prostitute as someone fundamentally different from the writers themselves. I argue that the writers construct the figure of the prostitute as a sexual 'other,' as a figure that is needed to demonstrate the line between the healthy and the sick or the suitable and the unsuitable.

My analysis attempts to connect the discussion on prostitution to the construction of acceptable and desirable Estonian sexual and gendered positions. The legalisation of prostitution was debated in Estonia during the years immediately after the collapse of the Soviet Union. As Mikko 
Lagerspetz has demonstrated, this debate not only addressed prostitution-related problems per se, but also raised questions on where the newly re-independent nation should be heading (118). The life writings under review reveal how the figure of the prostitute was formed as a needed outsider of the national community. Just as heterosexuality needs the forbidden homosexuality for its construction (e.g. Butler 98), normal and moderate heterosexuality needs what is perceived as excessive and abnormal, which in these writings is prostitution. This 'othered' figure of the prostitute is used by the writers to construct their own heterosexual self.

Historically, homosexuality and prostitution have been discussed within the same framework as vice and indecency (e.g. Weeks 49), but this connection has weakened during recent decades. In these Estonian life stories written in the early post-Soviet years, the topic of homosexuality is largely absent, even though homosexuality was discussed in the Estonian media of the time (Kurvinen 287-301). Furthermore, unlike early post-Soviet Russia, where lesbianism was portrayed as being more suspicious than male homosexuality because lesbianism so clearly opposes the patriarchal family model (Attwood 104-105), in the Estonian press of the time, lesbianism was presented as yet another way of offering women to the male gaze (Kurvinen 297-298). However, these writers on prostitution evoke similar associations of disease and personality flaws, as well as expressions of incomprehension, disgust and tolerance that have been discussed previously in relation to homosexuality (e.g. Cook 239-272).

As Matt Cook has analysed in his work on British Mass Observation reports, collections of personal accounts can diversify the "simplifications of cultural memory" (249). Equally, a collection of life stories is rarely if ever a representative sample but serves more as an indicator of possible conceptualisations in a certain historical situation. These narrations reflect the ways in which the writers, shaped by their own unique personality and experiences, interpret the world. In my research, life stories contribute to the understanding of how the all-too-familiar constructions of prostitution were used by the individual writers in the unique historical situation of post-Soviet Estonia.

In order to analyse these constructions, I have identified the themes that the writers mention as well as the expressions of emotions they adopt when discussing prostitution. Additionally, I have analysed the type of rationale the writers consider to be underlying the decision to sell sexual services or, more rarely mentioned, reasons for buying sex. As Cook has observed, personal accounts cannot be easily divided into clear-cut groups according to opinions, as the same writer may express contrasting views (248). Rather than analysing the differences between the opinions on prostitution or attempting to describe the popularity of different stances, 
my aim is to interpret the texts in light of the biographical understanding provided by the life story. I discuss how prostitution is associated with diseases, the type of ethnic implications it has and how it is interpreted as a stable phenomenon that cannot be abolished but needs to be controlled. Firstly, I analyse how the collection was shaped by the Finnish research project it was part of and the Estonian practices of life story writing.

\section{NARRATING SEXUAL LIFE IN A WRITTEN STORY}

In 1996, an appeal for writings was published in 18 Estonian newspapers and magazines. The call stated that Finnish sociologists needed Estonian life stories for their comparative analysis of the sexual lives of people around the Baltic Sea area. (The call is reprinted in Karusoo 5-6, from which the following descriptions and excerpts are cited.) This research on sexuality over the life course originated from sociological interest in sexuality. The study was connected to the FINSEX research project which conducted a major survey in 1992 to analyse Finnish attitudes towards intimate relationships and sexuality as well as sexual practices. In addition to the survey, a collection of life stories on sexuality was gathered the same year (Haavio-Mannila et al. 1-6). The researchers in that study traced the path of Finnish sexual liberation during the decades that followed the Second World War. After the collapse of the Soviet Union, the new situation in Eastern Europe offered an opportunity to study how these assumed progress trends were formed by the Soviet era. In that study, the utilisation of life stories as research material was connected to sociological life stories and life course research (Rotkirch 30-31).

The call for writings listed themes and questions that "the sociologists were interested in". These included sexuality in childhood, and the contributors were requested to comment on whether "the relationships between the man and the woman" were a taboo at home. Additional questions concerned sexually themed playing, sexual topics in school teaching and whether they had witnessed sexuality-related bullying or violence. The writers were asked about their first intercourse and its meaning. They were also requested to evaluate their sexual life and to mention if they have had disappointments or traumatic events and how they have received support from others. Moreover, some direct questions were posed: "What is your attitude towards extramarital sex? What is your opinion on prostitution? Sexual magazines?" By mentioning prostitution in the call questions, the researchers had already constructed prostitution as a topic within the domain of sexuality, and in the context of the 
research, acceptance of prostitution was considered to be an indicator of liberal sexual attitudes (e.g. Haavio-Mannila 226).

Some writers reported their hesitance and difficulty in addressing the topic of sexuality, and one of them described Estonians as "cold-spirited people of a northern country, who don't expose their feelings and worries to anyone". ${ }^{3}$ Even so, 61 writers ${ }^{4}$ replied to the call, remembering their life and describing their stances. The participants' years of birth range from 1909 to 1980, and geographically, they cover most of Estonia, although the writers are predominantly older people residing in the countryside (Luhaäär 234-235). Regarding the topic of prostitution, this means that the writers discuss their memories ranging back to the time of the Second World War.

The writings vary significantly in style as well as in length. The shortest texts are slightly over one page in length, and the longest are full autobiographies in the form of either thick hand-written notebooks or stacks of typed pages. Reminiscence writings and life stories typically mix different genres of writing and types of text, and fragmentary writing may be especially emblematic for post-socialist life stories (on published life writings, see, e.g. Karpinski 46-50; on the differences and similarities between published and unpublished reminiscence writings and the genres of life writings, see Savolainen 202-231). These life stories include, besides direct autobiographical prose narration, pieces of autobiographical fiction, poems, and one writer (15) supplemented his writing with a small text on prostitution that he had published in a newspaper.

The call for writings emphasised that all written should be true. The writers were instructed to write as if they were recounting their life to a trusted friend. Some writers responded to this request by crafting the story as told to a listener, such as one female writer (34) who wrote her life story as a discussion between two women who meet in a night train. Furthermore, the influence of the guiding questions is discernible in the texts. Roughly one-tenth of the texts is written in the form of autobiography steered by the questions posed. Approximately four out of ten writers added the answers to the question at the end of their writing or paused their life story to answer the questions before continuing again. That said, the writers also selected the questions they wanted to reflect on most, and ignored those they were not interested in.

In research, these writings have been utilised as an illustration of survey results on Estonian sexuality (Haavio-Mannila), in studies on love in life stories (Luhaäär) and women's life stories as well focusing on love and marriage (Hinrikus, "Deportation, Siberia"; Kurvet-Käosaar). A selection of the writings was also published as an anthology and worked into a play by Merle Karusoo in $1997 .{ }^{5}$ In all these utilisations, only some texts 
have been selected for analysis or presentation, and prostitution has not been discussed in detail. In her article, Elina Haavio-Mannila cites two excerpts of the writings to illustrate the Estonian attitudes towards and experiences of prostitution (170-175). In addition, Merle Karusoo's play, Kured läinud, kurjad ilmad, incorporates a life story in which prostitution plays an important role. This story recounts the experiences of a soldier in the German army during the Second World War, and I read it in relation to the importance of ethnicity in prostitution. However, my analysis of the material offers a novel perspective, as I focus on what is formed as marginal and 'other' in these life stories. By doing so, I attempt to demonstrate how the processes of marginalisation and othering form what is regarded as normal and how the 'othering' helps to construct the writers themselves.

When comparing the Estonian collection to the analysis of the Finnish life stories gathered in 1992, the impact of the phrasing in the call for writing becomes evident. According to Kontula and Haavio-Mannila, approximately one-fifth of Finnish male participants in the sexual life story collection described having bought sex themselves and, what the researchers find even more surprising, around six percent of female writers disclose that they have had sex for money. The researchers assume that as "paid love" was mentioned in the call, this may have encouraged the writers to discuss the topic. Regarding the women who have been paid for sex, Kontula and Haavio-Mannila assume that when a writer described an event in her own way, this enabled her to position herself as an active agent in her sex life, not solely as a passive receiver of the men's offers (523-543). In the Estonian call for writings, prostitution was one of the topics that requested more general opinions and fewer personal experiences, which offers one explanation for the lower number of personal memories regarding buying and selling sex than in the Finnish collection. Additionally, even though Finnish men wrote of their experiences with prostitutes abroad, and even mentioned Tallinn as one location to buy sex, the Estonian writers did not mention Finnish men paying for sex in Estonia.

Whereas the collection of life stories on sexuality and love was directly linked to the Finnish research project and the sociological interest in sexuality, it was likewise connected to the Estonian practices of collecting life writings. This was noted in the call, as it was stated that Estonia has a rather long tradition of collecting life stories. In the late 1980s, as Soviet policies allowed more diversity in the publication of historical accounts, the collection and publication of life stories began. When Estonia became independent in 1991, the collection work continued. (On this process, see Kõresaar and Jõesalu.) The gathering of writings was part 
of the memory boom of the last Soviet years and early post-Soviet years that was visible in Eastern and Central European countries (e.g. Luca and Kurvet-Käosaar). In newly re-independent Estonia, a new collective understanding of the national past was created (Kõresaar 10-16), and written life stories played an important role in this construction (Kõresaar and Jõesalu; Wulf 110-111).

The collection on sexuality and love life offered an opportunity for the authors to reveal the more intimate sides of the recent past. This aspect was even noted directly in the stories. For instance, one writer (11) stated that she had already written a life story in 1989 but did not dare to discuss the issues concerning sexuality at that time. ${ }^{6}$ Indeed, as Leena KurvetKäosaar has observed, the writers were offered complete anonymity in the call, which probably not only enabled them to discuss sexuality, but also facilitated addressing other topics, such as alcoholism or family violence, that would not otherwise be suitable for the cultural norms of a proper life story $(114-115 ; 125)$. Also, as the texts were intended for use by Finnish researchers, not for an Estonian audience, this probably encouraged the authors to share their hidden memories.

A characteristic Estonian feature of the post-Soviet memory boom was that the collection of life stories was compiled by gathering writings rather than by conducting oral history interviews that were popular in most post-socialist countries. Ene Kõresaar explains the success of the appeals for life writings by pointing to the tradition of public writing calls in Estonia dating back to Jakob Hurt's work on Estonian folklore in the late nineteenth century, and with the national importance associated with the organisations backing the work, such as the Estonian Literature Museum, Estonian National Museum and Estonian Heritage Society (Memory and History 12). When compared to the work of the 1980s and 1990 s, the collection of folk tradition and the ethnological study of Estonian peasant living in the nineteenth century already played an important part in developing the national identity and history of a people who quickly formed a nation (e.g. Kõresaar and Jõesalu). These traditions of constructing an individual life story within the frame of nationalism and national history also shaped how the writers crafted their understandings of sexuality.

The style of the writings were influenced by the nationalist framework of the post-Soviet life story collection as well as by the Soviet understanding and practices of life story writings. As Meike Wulf notes, during the Soviet era, writing an acceptable life story was a needed and often exercised skill (111). In the 1990s, some Estonian life story authors feared the potential consequences of their texts being stored in an archive should the Russians return (Hinrikus Preface ix), as the post-Soviet life stories 
also included those aspects of life that were omitted from Soviet-era life stories. This danger was referred to by one writer (7) in this collection, who replied anonymously because she had suffered in her life for stating her opinion. Furthermore, many of the writers noted how it was considered inappropriate to discuss sexuality in detail during the Soviet time or in the pre-war era, and they described the harm caused by the general ignorance of sexuality prevalent especially during their youth (see also Kurvet-Käosaar 122; on Russian post-Soviet life story writers, see Rotkirch, "What kind of sex"). Thus, even if the writers in the 1990s did want to write about their own sexual experiences, they still may not have felt comfortable addressing in detail a marginalised or despised sexual activity.

\section{DESCRIBING SELLING AND BUYING SEX}

As prostitution was one of the themes mentioned in the call, 37 of the 61 writers discussed it at least briefly by sharing their attitudes as well as personal experiences related to prostitution. The responses to the direct question on prostitution were mostly very concise, often only a few lines, while one writer (62) indicated only that the theme of prostitution was completely alien to her. Instead of answering the question or supplementing their answers, a total of eight writers-five men and three womendiscussed questions related to prostitution within their life story. Most of these were recollections of women described as prostitutes, or of the buying and selling of sex that the writers had witnessed. Even though the writers focused more on women who solicit sex than on the men who buy, the authors described women whom they did not know personally. There was, however, one exception-a female writer (21), born in 1942, wrote of her partner's daughter who had become a prostitute. While this came as a great shock to the father, the writer described it as a process beginning from his daughter's early interest in sex and sexual abuse during her childhood.

Two male writers told of their own experiences of paid sex. An account by a male writer born in 1942 reveals an interesting contradiction between how he described his attitudes towards prostitution and the type of personal experiences he wrote about. His life story is titled as "Memoirs of one 'slutty' man", 7 using a term in his positive self-identification that can likewise refer to prostitutes. He recalled an encounter that took place when he was young and living in a communal apartment in the late 1950s. As he returned to his apartment after visiting his parents, he found a half-drunken woman in the room he shared with other young men. He had sex with her, which he paid for with a bottle of wine and some snacks: 
The girl was a real specialist in her field and she hardly did it for some bottle of wine. No, she enjoyed it herself. [...] During that hour I got more information and skills than reading through whole 'Marriage technique' [an Estonian book on sex counselling from the year 1926 - RT] + practical experiences. [...] And all of that for just a bottle of wine and some buns. Compared with the price of sexual services today, it was almost free. But well—she was just an easy slut enjoying life, not today's qualified prostitute. ${ }^{8}$

This writer emphasised both the possibility of gaining novel sexual experiences, which is a commonly stated reason for buying sex (Marttila 37), and that sex was likewise enjoyable for the woman. After recalling this encounter, the writer continued to answer the question on prostitution as he already had pursued the topic. He described the current selling of sexual services, and continued:

In fact, I think every woman is a prostitute in some sense-all the same for what she sells her body. Whether she is paid in cash, is taken to restaurants and theatres or where ever. Or is she buying with her body the love of her beloved man. Being cynical one could state that every wife is the prostitute of her husband-in a way she buys peace at home, independence as a housewife, man's acceptance and love. The variants are numerous. Naturally those examples are extreme and absurd, but really it can be seen in this way. ${ }^{9}$

This description of selling sex in general does not seem to conform to this writer's own experience of paid sex. In the text cited above, the author highlighted the importance of sex itself to the woman referred to as "a real specialist". Thus, this author argued that paid sex is enjoyable in itself, but still he maintained that not only for prostitutes, but for women in general, sex has predominately an instrumental value. Furthermore, he characterised many of his partners in his life story as women who sought sexual fulfilment and that for him, his affairs had offered him the friendship and recognition that he had longed for in his childhood. In this way, the descriptions of personal experiences of prostitution may stand in contrast to how the phenomena is perceived in general, even by the same writer.

\section{FULFILLING A STABLE NEED—PROSTITUTION IN SOCIETY}

The Soviet Union officially treated prostitution as non-existent, or something that would eventually be eradicated as socialism proceeded. According to Lagerspetz, during the Estonian 1993-1994 debate on the legalisation of prostitution, some expressed "Marxist-Leninist" notions 
that portrayed prostitution as a by-product of a capitalist society and as a consequence of marketisation in the post-Soviet years (122). However, none of the life story authors supported the viewpoint that prostitution would not have existed during the Soviet times. One writer even directly opposed this viewpoint: "Some naive people say, though, that there was none during Soviet time. There was, but it was hidden underground. It was not as open as today." 10

Many writers emphasised that prostitution has always existed, and it cannot be eliminated. A female writer born in 1968 stated the following:

The problem is probably as old as humankind. It has never been abolished, as there is always supply and demand. Evidently the representatives of "the oldest profession" are needed and evidently some women like the profession. ${ }^{11}$

This excerpt portrays prostitution as fulfilling a stable societal need and that some women even enjoy it. Prostitution is conceived of as being inevitable and, in essence, natural. Although some writers cannot fully comprehend why, they assume that some men simply need to buy sex. One writer (10) stated that just as people have different needs for sleep or nutrition, they also have different needs for sex. This opinion of the need for prostitution as something natural is further emphasised by some writers who refer to the possibility that women can also pay for sex when they themselves need it. This eliminates the possible interpretations of prostitution as a sign of gender inequality, and the gendered aspects of the sex trade are portrayed as merely dependent on the situation.

The writers also expressed their incomprehension of men buying sex as well as women selling sexual services. A female writer, born in 1953, associated sex with lasting, loving relationships only:

I find prostitution totally unthinkable. I do not, nor even want to, understand those women. A woman should not be so cheap. Paid millions are not worth femininity. All in life should not be for sale. Love is not to be bought. ${ }^{12}$

This writer contradicts the viewpoint that selling sex could be explained solely in terms of the economic situation of the woman selling. To this author, not even millions would compensate for the loss to a woman. These opinions might be attributed to the author's own life history as a victim of rape and the associated shame she felt long after, which may have made the idea of sex without love seem repulsive and violent.

The reasons for selling sexual services were predominantly assumed qualities that were inherent to women-their excessive sexuality, outright nymphomania or even physical differences. Two writers $(21,35)$ who 
recall women described as prostitutes perceived these women's position as resulting from rapes or sexual abuse. Only one writer cited the possibility that prostitution may be the only option for some women's economic survival. A woman born in 1957, who is also the only writer self-identified as Russian by nationality, wrote that she cannot judge those who "in this expensive life" need this option, as it cannot be an easy choice and besides, people do crazier things for money. She contemplated the reasons why some women sell sexual services while others do not: "Not every woman becomes a prostitute, so I do not know who to blame, the woman herself, those who brought her up or the state where she lives." ${ }^{33}$ She wrote that she has had several partners in her life, and as her story unfolds, she described many of these relationships as unhappy, but she states that she "has not sold herself".

Even though the female writers were the ones who described prostitution as incomprehensible, they were able to relate to the position of a prostitute and imagine how life would be during or after selling sex. They described the economic insecurity of a former prostitute, as she would not be entitled to either social security or a pension. But this economic position is not the only aspect that the writers envision as being difficult for a former prostitute. For example, one writer (57) connected the problems of life after leaving prostitution to the high level of income and lifestyle. According to her, no man would tolerate a wife who had earned a high standard of living by selling sex. The same writer stated that prostitutes in Estonia are a privileged class as they do not pay taxes on their income. Furthermore, the notion of prostitutes' high income is mentioned in two other submissions. These views probably originate from the late Soviet era, when prostitution could have offered an access to hard currency and Western products not publicly available. Also, the post-Soviet discussion on prostitution portrayed the selling of sexual services as a new opportunity offered to women by capitalism in Estonia (Kaskla 307-308) as well as in Russia (Bridger and Kay 32-35). By claiming the personality traits of the prostitute as a basis for selling sex and by mentioning the high incomes from the sex trade, prostitution was associated with the excessive interest in both sexuality and consumerism.

Due to an assumed high income, the selling of sexual services could be regarded as a tempting option. A male writer born in 1946, who answered the questions posed in the call with excerpts of his autobiographical manuscripts, included a short text he had published in an Estonian tabloid:

I make a suggestion that prostitution as such could be legalised in Estonia under one condition: the salary of the prostitutes may not exceed the minimum salary prescribed by law. I leave it to the legislators how it could be controlled. This kind of salary would make most of the prostitutes search 
for a profession that does not devalue women. Let those prostitutes who are satisfied with such a salary continue their 'work' under the control of the vice squad and doctors. A low 'income level' puts all on the same footing and gives a possibility to satisfy one's desires for ordinary drifters as well as possible rapists, not to mention the rich business men. ${ }^{14}$

Although this writer interpreted selling sex as something that is degrading to women, it seems that a greater concern for him was that men have unequal access to the services provided. He portrayed prostitution as contributing to a common good and, further, that for women in prostitution, their work is sufficiently important that they would oblige men for a minimum salary. This author also argued that prostitution may benefit the entire community because access to paid sex could prevent rape. $\mathrm{He}$ also mentioned that the real beneficiary of the current situation is the mafia, which collects the big money. Still, with organised crime involved, buying and selling sex was understood as filling such a fundamental need in society that it could not be wiped out.

\section{PROSTITUTION AS AN INFECTIOUS DISEASE}

The life stories link prostitution to the threat of spreading sexually transmitted diseases (STDs). In an effort to prevent AIDS spreading, some writers stated that prostitution needs to be controlled. Concerning STDs, this position reveals striking parallels between the treatment of female prostitutes by the Estonian life story writers and of the gay men by the British Mass Observers. During the 1980s, many people in the Western countries associated AIDS with homosexuality, even to the extent that the disease was commonly referred to as the "gay plague" (e.g. of Britain, Weeks 98-103). This is also visible in the analysis by Cook: some British writers blamed gays for spreading AIDS or at least for getting themselves infected. These writers were ready to implement the compulsory testing of gays and to exclude them from health care because they were perceived as outsiders who did not deserve the rights granted to others (251-252). Similarly, some of the Estonian writers who discussed prostitution were ready to withdraw the right for publicly paid medical care from those who were considered to be responsible for being infected and called for compulsory testing and control. One Estonian writer even welcomed AIDS and only regretted that there were so few cases, as the disease would wipe out "the most promiscuous among the promiscuous men and women", ${ }_{15}$ decrease the amount of casual sex and increase the value of marital fidelity. This, too, echoes the calls by the Mass Observers for more monogamous behaviour and enhancement of the couple norm (Cook 263-269). 
As prostitution was mentioned in the questions posed to the writers, it is very understandable that the Estonians discuss it significantly more than homosexuality, which was absent from the call. Would the call have been phrased differently, the connection between homosexuality and AIDS could have become visible, as gay men as a group with a heightened risk of HIV was discussed in Estonia in the late 1980s (Kurvinen 292-295; Nõgel 115). However, the media discussion had shifted at the beginning of the 1990s, and the connection between homosexuality and AIDS weakened (Kurvinen). That said, as the topic of STDs or AIDS was not mentioned in the call, I interpret the writings as an indication of how the connection between prostitution and the STDs was stronger in Estonia during the mid-1990s than that between homosexuality and STDs or AIDS.

In addition to preventing disease, another reason mentioned in the life stories for the need to control prostitution was the danger of child abuse. As a female writer born in 1968 observed: "I'm not against prostitution when it is under control and minors are not involved." 16 The danger of minors in prostitution was connected to the danger of the spreading not only of diseases, but of prostitution as if it were a disease. A female writer born in 1925 stated, emphasising both the permanence of prostitution as well as a thread that it could be spreading: "There has always been people with an abnormal, sick interest in sex, and there will be even more in the future as sexiness is being emphasised and overrated." 17 Portraying prostitution as a disease differentiates the prostitute from other women and thus ensures the latter that their normal way of life is not endangered because only abnormal women are engaged in this type of promiscuous behaviour (cf. Attwood 114-115). As discussed above, prostitution is portrayed as something profoundly corruptive-a woman soliciting sex is infected for life, as the difficulties and shame will haunt her. Despite this type of contrast between the 'other' prostitute and 'us' that is expressed in the texts, the prostitute serves a function in society that is perceived as permanent and needed. As the prostitutes cannot be completely excluded, they need to be included as a controlled 'other' in society.

One of the most frequently used Estonian words for prostitution in the texts is litsilömine, and the primary meaning of this word is promiscuity, not only sex for money. As the same term refers to different types of promiscuous or casual sex, one that is paid for and another that is not, I have analysed how these forms are commented on by the writers. As an illustration of the differences discovered, two female writers expressed contrasting views on the possibility that their partner would deceive them with a prostitute. A woman born circa 1962 wrote that although she would not like her husband to buy sex due to the probability of him contracting 
diseases, still a relationship with a prostitute would eliminate the idea of him leaving the family: "One would not marry a prostitute, but a young mistress may start to ask for something sooner or later..." ${ }^{18}$ On the other hand, a female writer born in 1935, who assumed that men frequent prostitutes to acquire some sexual experiences that are not offered at home, nonetheless interpreted it as infidelity and stated: "I think I would rather relent if my beloved would be promiscuous with a so-called normal woman than a prostitute." ${ }^{\prime 9}$ The difference in these statements can be explained both by the generation and age of the writers; the respondent who considers prostitution to be worse than infidelity is past the point in her life when she had young children and a spouse leaving the family would constitute economic hardship.

The writer cited above was in her sixties and recounted that she never had extra-marital affairs and she is certain that neither had her husband. In fact, she declared this as a reason for writing because she assumed that older people who appreciated fidelity would rarely respond to the call. To a certain extent, considering the whole collection, she is correct: writings that describe extra-marital affairs are common, and generally these affairs are not portrayed as completely unacceptable. Indeed, the writers referred to the Estonian phrase "fidelity is a lack of opportunity", ${ }^{20}$ and about half of them described relationships in which either they themselves or their partner had another affair simultaneously. The writers told of how affairs were forgiven or how sometimes the partners proceeded for a long time while acknowledging the other relationships on the side. Thus, the line between normal infidelity and affairs, on the one hand, and abnormal prostitution, on the other, becomes important, as prostitution is regarded as an excessive, abnormal form of infidelity that is rather pervasive. This difference is blurred, however, as several writers mention that some prostitution occurs without an exchange of money, but by exchanging services or goods (on Soviet prostitution and sexuality as means of exchange in life stories describing Soviet Russia, see Rotkirch, The Man Question 203-207).

\section{PROSTITUTION, ETHNICITY AND NATIONAL SHAME}

Ethnicity plays diverse roles in the writers' discussion on prostitution. If prostitution is perceived as devaluing women, by ethnic othering, this degradation can be justified. In other words, prostitution affects other women, not those of one's own nationality. Moreover, women of other ethnicities can be considered to be sexually attractive and some ethnicities may be associated with overwhelming sexuality. One female writer in this collection, born in 1923, depicted prostitution as typical of Russian 
women. She recalled her years as a deportee in Siberia during and after the Second World War and, according to her, one could encounter women in Russia who were nymphomaniacs, hypersexual and even ready to pay for men for sex (26). The Russian nationality of prostitutes is also mentioned in two other life stories that describe encounters with prostitutes. These, however, seem to be more descriptive statements of the nationality of the women or the language spoken by them, not indications that prostitution would be typical for Russians.

Additionally, the public discussion in Estonia portrayed prostitution as a Western, capitalist, import (Lagerspetz 122). Thus, something unrelated to either Russia or to the West would be needed to overcome it. A female writer (7) born approximately in the 1920s, who wrote her reply in Finnish to address directly the Finnish researchers, expressed her concern about the spread of prostitution. This writing included few if any experiences or memories and concentrated on the problems of the public display of sexuality and violence. The writer called for small nations, such as Finland and Estonia, to create something beautiful, something not associated with the 'madness' of the West. This writer appears to appeal for another solution for small, independent nations-a notion that has been popular in Estonia on several occasions throughout history. Just as during the Second World War, when Estonians joined the Finnish army in the wars against the Soviet Union as an alternative to avoid both the Soviet and German armies (Kõresaar, "Boris Takk"), here, too, Finland serves as a companion for the Estonian third alternative.

A contribution by a male writer born in 1927 exoticises prostitution. This writer remembered his experiences during his time as a young volunteer in the German army in 1943. During the Second World War, Estonians were either volunteers or conscripts in the Soviet army as well as in the German army. After the war, as the Soviet annexation continued, only the memory of those who served in the Soviet troops was recognised, and many of those who had been often involuntarily drafted into the German army or who had volunteered in Finland faced charges for betraying their homeland (e.g. Rahi-Tamm 252-253). However, in the 1990s, those who served in the German army still struggled for recognition as fighters for Estonian independence (Kõresaar, "Remembrance Cultures" 7-10).

From this contested memory position of a young Estonian in the SS troops, the writer described his time in military training in Poland in 1943. He became acquainted with a prostitute, whom he refers to here as a "night butterfly of the brothel"21: "Her name was Eirene (in Greek, peace). A Greek from the Crimea." ${ }^{22}$ Later in the story, the woman's thick, dark hair as well as her darker complexion are described as aspects of her beauty, and he stated that she had received her education as a prostitute 
from Asian teachers in France. The story is a detailed description of the war-time romance between the prostitute and the soldier, closely resembling a sexual fantasy, and the style of the text has similarities to the sexual life stories published in pornographic magazines (for a similar reading of the Russian life stories, see Rotkirch, The Man Question 36-37). This encounter resembles the account of youth experience mentioned above in that it describes receiving instruction on sexuality. In this particular narration, however, the writer emphasises emotional connection and describes their relationship as loving and his own emotions as reflecting his attachment to the woman. Later in his story, the writer even referred to the possibility that the woman bore a son as a result of their war-time affair.

In contrast to the exoticising notions or those that place prostitution as foreign, one writer described it as characteristic of Estonians:

During the German occupation the Germans stated cynically-pull a roof over Estonia and you get one big whorehouse. And with bitterness one must admit that the Germans spoke the truth. The nationwide whoring with the Germans was like a bad disease that spread over Estonia. Only the children and those who walked with a cane were untouched by the disease. ${ }^{23}$

In this excerpt, prostitution is connected to the special situation of the German occupation (1941-1944), and prostitution is referred to as a spreading illness. In more general remarks, prostitution was considered to be something daily and natural for 'us' by a writer who remarked that his writing on the topic did not receive attention (15).

Moreover, one of the emotions at work when discussing prostitution is evidently shame-it is the shame that the writers assume prostitutes or those around them feel (e.g. 23), but it is also a feeling of national shame. Uncontrolled prostitution, most likely referring to the post-Soviet situation that brought underground prostitution to the surface (e.g. Kaskla 307), was portrayed as shameful for the nation. A male writer stated that "When it comes to prostitution, it is the disgrace of every state" 24 (emphasis original). This writer had, however, described how earlier in his life, during his time at the sea, the women on the ship were earning extra income by soliciting sexual services, and he stated that prostitution is very much needed for the men who spend a long time at sea-although he himself stayed true to his spouse waiting at home. Thus one concludes from these statements that controlled prostitution is needed and not shameful-at least when it takes place outside Estonia.

Some writers referred to Estonia as a free country, with everyone free to do as they wish, including engaging in prostitution. In a free country, one cannot forbid selling sex. And why should it even be forbidden, as 
that would not erase the oldest profession in the world? However, the new post-Soviet situation appeared to have raised new concerns of markets penetrating all areas of life. This position was also visible in the public debate on prostitution, in which some thought it important to protect at least some aspects of life from all-embracive capitalism (Lagerspetz 121-122).

\section{CONCLUSIONS}

This article has discussed the construction of prostitution and the figure of the female prostitute in Estonian life stories collected in 1996. These writings were compiled for comparative research on sexuality around the Baltic Sea area and the project was initiated by a team of Finnish sociologists. By calling for writings, the participants were offered an opportunity to discuss private aspects of Estonian recent past and to produce understandings of post-Soviet sexuality in Estonia. These life stories were crafted by the individual writers in the space offered by the call. The collection was framed by sociological research, Estonian practices of life-story writing and collecting, and by the prominence of life stories in the Estonian nation-building and reclaiming of its national past in the early 1990s.

I have analysed how the writers referred to a prostitute as a figure of 'other,' which is used to draw the line between acceptable sexuality and that which is considered to be abnormal. Prostitution is exoticised and thus depicted as non-Estonian, likened to an illness as well as associated with AIDS and other STDs. These notions of prostitution as a spreading vice and its association with AIDS come close and have parallels to notions connected to homosexuality, which is not used in these life stories as an othered figure distanced from the norm and the writers themselves. As often is the case when discussing prostitution, the writers focus considerably more on the women who solicit sexual services than on men who buy sex and the reasons underlying prostitution are attributed to the abnormality of the women.

In these life stories, prostitution is addressed with incomprehension as well as indifference towards the choices that others make in life: in the newly re-independent Estonia, everyone should be free to do as they pleased. Prostitution is also characterised as something that cannot be eradicated, as there will always be both demand and supply. Prostitution therefore fulfils a stable and, in essence, natural need in society. Prostitution is also portrayed as serving a common good, something needed both by the women who sell sexual services as well as the men who buy. The notions of prostitution as gendered exploitation are further challenged, as it is proposed that even women can pay for sex when they 
need it. However, some writers argue that prostitution needs to be controlled to reduce the harm caused by it, such as the spread of diseases and the threat posed to children. In short, the writers therefore conceive of uncontrolled prostitution as the major problem and it is depicted as a disgrace for Estonian women and the Estonian state. Controlled prostitution can be included as an internalised other to the national community, one that even offers protection as access to paid sex was thought to prevent rape.

Why is it that this figure of the female prostitute as othered was constructed in these life stories? One of the important demarcations of these writings is drawn between proper heterosexual relationships, even those involving infidelity, and the overtness associated with prostitution. The figure of the uncontrolled, excessive prostitute is used to construct the vision of the controlled and moderate Estonian female sexuality. Indeed, perhaps one aspect that arose as something despicable regarding female prostitutes was the sexual and financial autonomy associated with the figure of the well-off prostitute-a figure that, of course, hardly corresponded to the lives of actual women selling sex.

\section{WORKS CITED}

Annuk, Eve. Naised Kõnelevad. Tartu: Eesti Kirjandusmuuseum and Eesti elulood, 1996.

Attwood, Lynne. "Young People, Sex and Sexual Identity." Ed. Hilary Pilkington. Gender, Generation and Identity in Contemporary Russia. London: Routledge, 1996. 95-120.

Bridger, Sue and Rebecca Kay. "Gender and Generation in the New Russian Labour Market." Ed. Hilary Pilkington. Gender, Generation and Identity in Contemporary Russia. London: Routledge, 1996. 21-38.

Butler, Judith. Gender Trouble. Feminism and the Subversion of Identity. New York: Routledge, 1990, 1999.

Cook, Matt. "AIDS, Mass Observation, and the Fate of the Permissive Turn." Journal of the History of Sexuality 26.2 (2017): 239-272.

Haavio-Mannila, Elina. "Seksuaalsed Tavad ja Hoiakud Eestis." Ed. Olav Poolamets, Elina Haavio-Mannila, Osmo Kontula, and Kai Haldre. Seksuaalsus Eestis. Ajalugu. Tänapäev. Arengud. Tallinn: Eesti Akadeemiline Seksoloogia Selts, 2006. 101-232.

Haavio-Mannila, Elina, Osmo Kontula, and Anna Rotkirch. Sexual Lifestyles in the Twentieth Century: A Research Study. Houndmills: Palgrave, 2002.

Hinrikus, Rutt. "Deportation, Siberia, Suffering, Love. The Story of Heli." Ed. Tiina Kirss, Ene Kõresaar, and Marju Lauristin. She Who Remembers Survives. Interpreting Estonian Women's Post-Soviet Life Stories. Tartu: Tartu University Press, 2004. 62-88.

Hinrikus, Rutt. Preface. Ed. Tiina Kirss. Estonian Life Stories. Budapest: Central European University Press, 2009. v-xii.

Karpinski, Eva. "Postcards from Europe: Dubravka Ugrešić as a Transnational Public Intellectual, or Life Writing in Fragments." European Journal of Life Writing 2 (2013): T42-T60, http://ejlw.eu/article/view/55. Accessed 14 June 2017.

Karusoo, Merle. Kuret Läinud, Kurjad Ilmad. Tartu: Eesti Kirjandusmuuseum, Eesti elulood and Maalehe raamat, 1997. 
Kaskla, Edgar. "The National Woman: Constructing Gender Roles in Estonia." Journal of Baltic Studies 34.3 (2003): 298-312.

Kontula, Osmo and Elina Haavio-Mannila. Matkalla Intohimoon. Nuoruuden Hurma ja Kärsimys Seksuaalielämäkertojen Kuvaamana. Porvoo: WSOY, 1995.

Kontula, Osmo and Elina Haavio-Mannila. Intohimon Hetkiä. Seksuaalisen Läheisyyden Kaipuu ja Täyttymys Omaelämäkertojen Kuvaamana. Porvoo: WSOY, 1997.

Kõresaar, Ene. Memory and History in Estonian Post-Soviet Life Stories. Private and Public, Individual and Collective from the Perspective of Biographical Syncretism. Tartu: Tartu University Press, 2004.

Kõresaar, Ene. "Remembrance Cultures of World War II and the Politics of Recognition in Post-Soviet Estonia: Biographical Perspectives." Ed. Ene Kõresaar. Soldiers of Memory. World War II and Its Aftermath in Estonian Post-Soviet Live Stories. Amsterdam: Rodopi, 2011. 1-34.

Kõresaar, Ene. "Boris Takk-The Ambiguity of War in a Post-Soviet Life Story." Ed. Ene Kõresaar. Soldiers of Memory. World War II and Its Aftermath in Estonian Post-Soviet Life Stories. Amsterdam: Rodopi, 2011. 343-363.

Kõresaar, Ene and Kirsti Jõesalu. "Post-Soviet Memories and 'Memory Shifts' in Estonia." Oral History 44.2 (2016): 47-58.

Kurvet-Käosaar, Leena. "'Not Much Love Lost Between Me and My Husband': Love in Estonian Women's Life-Stories of the Soviet Period.” Eds. Melanie Ilic and Dalia Leinarte. The Soviet Past in the Post-Socialist Present. Methodology and Ethics in Russian, Baltic and Central European Oral History and Memory Studies. New York: Routledge. 2015. 110-128.

Kurvinen, Heidi. "Homosexual Representations in Estonian Printed Media during the Late 1980s and Early 1990s." Eds. Roman Kuhar and Judit Takács. Beyond the Pink Curtain. Everyday Life of LGBT People in Eastern Europe. Ljubljana: The Peace Institute-Institute for Contemporary Social and Political Studies, 2007. 287-301.

Lagerspetz, Mikko Constructing Post-Communism. A Study in the Estonian Social Problems Discourse. Turku: Turun yliopisto, 1996.

Luca, Ioana and Leena Kurvet-Käosaar. "Life Writing Trajectories in Post-1989 Eastern Europe." European Journal of Life Writing 2 (2013): T1-T9. http://ejlw.eu/article/view/51. Accessed 14 June 2017.

Luhaäär, Ingvar. "Armastus Eesti Seksuaaluuringu Valgusel.” Eds. Olav Poolamets, Elina Haavio-Mannila, Osmo Kontula, and Kai Haldre. Seksuaalsus Eestis. Ajalugu. Tänapäev. Arengud. Tallinn: Eesti Akadeemiline Seksoloogia Selts, 2006. 233-246.

Marttila, Anne-Maria. "Desiring the Other: Prostitution Clients on a Transnational Red-Light District in the Border Area of Finland, Estonia and Russia." Gender, Technology and Development 12.1 (2008): 31-51.

Nõgel, Ivika. "How Homosexuality Is Regarded Among Students in Current Estonia." Eds. Udo Parikas and Teet Veispak. Sexual Minorities and Society. The Changing Attitudes Toward Homosexuality in $20^{\text {th }}$ Century Europe. Papers Presented to the International Conference in Tallinn May 28-30, 1990. Tallinn: Eesti teaduse akadeemia ajaloo instituut, 1991. 115-121.

Rahi-Tamm, Aigi. "Aleksander Loog-Searching for One's Way: The Opportunities and Choices of Estonian Men During the Political Changes of the 1940s.” Ed. Ene Kõresaar. Soldiers of Memory. World War II and Its Aftermath in Estonian Post-Soviet Life Stories. Amsterdam: Rodopi, 2011. 235-262.

Rotkirch, Anna. The Man Question. Loves and Lives in Late $20^{\text {th }}$ Century Russia. Helsinki: University of Helsinki-Department of Social Policy, 2000.

Rotkirch, Anna. “'What Kind of Sex Can You Talk About?' Acquiring Sexual Knowledge in Three Soviet Generations." Eds. Daniel Bertaux, Paul Thompson, and Anna Rotkirch. On Living Through Soviet Russia. London: Routledge, 2004. 93-119.

Savolainen, Ulla. "The Genre of Reminiscence Writing. Applying the Bahktin Circle's Genre Theories." Eds. Kaarina Koski, Frog, and Ulla Savolainen. Genre-Text-Interpretation. 
Multidisciplinary Perspectives on Folklore and Beyond. Helsinki: Suomalaisen Kirjallisuuden Seura, 2016. 202-231.

Weeks, Jeffrey. The World We Have Won. The Remaking of Erotic and Intimate Life. London: Routledge, 2007.

Wulf, Meike. Shadowlands. Memory and History in Post-Soviet Estonia. New York: Berghahn Books, 2016.

\section{ABOUT THE AUTHOR}

Riikka Taavetti received her Master of Arts in archival science from the University of Jyväskylä and a Master of Social Sciences from the University of Helsinki, where she is currently a doctoral candidate in political history at the Department of Political and Economic Studies. The topic of her dissertation is queer memory, archives and life stories in Finland and Estonia. Her most recent publications address queer Archives ["A Marshall in Love. Remembering and Forgetting Queer Pasts in the Finnish Archives.” Archival Science 16 (2016): 289-307, DOI 10.1007/s10502-015-9251-7] and queer youth life stories ["Reflecting the Queer Me. Memories of Finnish Queer Youth From the 1950s Onwards." Lambda Nordica 3-4 (2016)]. She is associated with the LivingMemories research project (http:// www.livingmemories-era.net/), which focuses on diverse identities and shared experiences of traumatic memories in six European societies.

\section{NOTES}

1 I wish to thank the members of the Editorial Board as well as the anonymous reviewers of the European Journal of Life Writing for their most valuable comments. I also want to thank Andreas McKeough, PhD, for checking my translations from Estonian, and Senior Lecturer Kate Moore for thorough editing of the text.

2 "Prostitutsioon ongi seks raha pärast. Ta on maailma vanim elukutse ja eks ole igaühe oma asi, kuidas ta raha teenib. Milleks süüdistada prosituute, kui 'truud' abielumehed käivad karjakaupa nende teenuseid kasutamas." Eesti Kirjandusmuuseum. EKLA f 350a. Elulood. Erikogu 39. I refer to the writings in the collection of Estonian life stories on love-life and sexuality by the number assigned to them in the Estonian Literature Museum collection. All translations of the excerpts are mine.

3 "külma hingega põhjamaa rahvas, kes oma tundeid ja muresid kellegi ei avalda" (10).

4 There are minor inaccuracies between different sources regarding the precise number of the writings. The consecutive numbering of the writings in the original collection archived in Estonian Literature Museum runs from 1 to 62, but has number 61 missing, presumably by accident. In addition, writing number 52 was withdrawn from the collection after sending, but it seems to be included in the data used by Finnish researchers (Haavio-Mannila, Elina \& J.P. Roos: Sexual Autobiographies of Estonians 1996. FSD2545, version 1.0 [2010-08-11]. Tampere: Finnish Social Science Data Archive, 2010).

5 In addition, two of the writings have been published among other women's life stories in the collection of Naised kõnelevad (Annuk).

6 According to Haavio-Mannila and Kontula, sexuality is often omitted from a life story if the call does not explicitly ask about it (Haavio-Mannila and Kontula 1995, 21). 
7 "Ühe 'litsaka' mehe memuaarid".

8 "Tüdruk oli oma ala tõeline spetsialist ja vaevalt tegi ta seda mingi pudeli veini eest. $\mathrm{Ei}$, ta tundis asjast isegi mõnu. [...] Selle tunni jooksul sain rohkem teadmisi ja oskusi kui terve "Abielutehnika" läbilugemisel. + praktilised kogemused. [...] Ja kõike seda vaid pudeli veini ja paari kukli eest. Tänapäevä seksiteenuste hindu arvestades oli see peaaegu tasuta. Aga noh—-tema oli vaid lihtne elust lõbu tundev litsike, mitte tänapäevä kvalitfitseeritud prostituut" (49).

9 "Tegelikult arvan, et iga naine on teatud mõttes prostituut-ükskõik mille eest ta oma keha müüb. Kas makstakse talle sularahas, viiakse restorani, teatris või kuhu iganes. Või ostab naine oma kehaga armastud mehe vastuarmastust. Küünilisemaks minnes võib öelda, et iga naine on oma mehe prostituut— ta ostab teatud mõttes kodurahu, pereema seisuse, mehe poolehoiu ja armastuse. Variante on tohutult palju. Loomulikult on eelpooltoodud näited äärmuslikud ja absurdsed, aga tegelikult seal asjale ka nii vaadata" (49).

10 "Mõni naiivne ütleb küll et nõugokude ajal ei olnud. Oli, aga see oli põranda alla peidetud. Ei olnud nii avalik kui praegu" (2).

11 "See probleem on vist sama vana kui inimkond. Likvideerida pole seda kunagi suudetud, alati on olemas nii nõumine kui pakkumine. Küllap on siis 'vanima elukutse' esindajad vajalikud ja küllap on naisi, kellele see elukutse on meelde" (31).

12 "Minu jaoks on prostitutsioon täiesti mõeldamatu. Mina neid naise ei mõista ega ei tahagi mõista. Nii odav ei tohiks naine olla. Makstud miljonid ei vääri naiselikkust. Kõik ei tohi olla elus kaup. Armastus ei ole ostetav" (13).

13 "Iga naine ka prostituudiks ei hakka, nii, et ma ei teagi, keda süüdistada, kas naist ennast, tema kasvatajaid, või riigi, kus ta elab" (30).

14 "Teen ettepaneku prostitutsioon kui niisugune Eestis vastava seadusega legaliseerida, kui ainult ühel tingimusel: libude kuupalk ei tohi ületada meil seadusega kehtestatud kuupalka alammäära. Mis moodi seda kontrollida, jäägu seaduseandjate mureks. Niisugune palk sunniks enamikku libusid otsima endale tööd, mis ei alanda naise väärikust. Need libud aga, keda niisugune palk rahuldab, tehku oma "tööd" kombluspolitsei ja arstide järevalve all usinasti edasi. Madal "teenustasu" paneb kõik ühele pulgale ja võimaldab oma isasi rahuldada nii tavalise paadialusel, kui potentsiaalsel vägistajal, rikkast ärimehest rääkimata" (15).

15 "litsidest litsamad mehed ja naised" (59).

16 "Ma ei ole prostitutsiooni vastu, kui see on kontrolli all ja ei kaasata alaealisi" (31).

17 "Ebanormaalne haiglasliku seks huviga inimesi on alati olnud ja saab olema tulevikus veelgi rohkem, kui seksikust rõhutatult üle hinnatakse" (14).

18 "Löbunaistega ju ei abielluta, aga noor armuke võib varem või hiljem hakata midagi noudma..." (51).

19 "lepiksin võibolla enne sellega, et mu armsamal oleks mõni juhuslik vahekord nn. normaalse naisega kui prostituudiga" (57).

20 "Truudus on juhuse puudus."

21 "bortelli ööliblikas."

22 "Nimi Eirene (kreekak. rahu). Krimmi kreeklane" (50).

23 "Saksa okupatsiooni ajal ütlesid sakslased küüniliselt-Tõmba Eestimaale katus peale ja saab ühe suure litsimaja. Ja kibedusega peab ütlema, et sakslase ütlesid tõtt. See üleriigiline litselöömine sakslastega oli nagu halb tõbi mis siis ule Eestimaa käis. Puutumata selles tõvest jäid täiesti lapsed ja need kes juba kepiga käisid" (2).

24 "Mis aga puutub prostitutsioon, siis on sellike asi iga riigi häbiplek!" (29). 